\title{
Assessment of the Effect of A-PRF Application during the Surgical Extraction of Third Molars on Healing and the Concentration of C-Reactive Protein
}

\author{
Jacek M. Nowak ${ }^{1, *(0)}$, Stanisław Surma ${ }^{2}$, Monika Romańczyk ${ }^{2}$, Andrzej Wojtowicz ${ }^{1}$, Krzysztof J. Filipiak ${ }^{3}{ }^{(0)}$ and \\ Maciej R. Czerniuk ${ }^{1}$ \\ 1 Department of Dental Surgery, Medical University of Warsaw, 02-091 Warsaw, Poland; \\ andrzej.wojtowicz@wum.edu.pl (A.W.); maciej.czerniuk@wum.edu.pl (M.R.C.) \\ 2 Faculty of Medical Sciences in Katowice, Medical University of Silesia in Katowice, 40-752 Katowice, Poland; \\ stasiu.surma@onet.eu (S.S.); monika.romanczyk@med.sum.edu.pl (M.R.) \\ 3 Maria Sklodowska-Curie Medical Academy in Warsaw, Pałac Lubomirskich, 00-136 Warsaw, Poland; \\ krzysztof.filipiak@uczelniamedyczna.com.pl \\ * Correspondence: jacek.nowak@wum.edu.pl
}

Citation: Nowak, J.M.; Surma, S.; Romańczyk, M.; Wojtowicz, A.; Filipiak, K.J.; Czerniuk, M.R. Assessment of the Effect of A-PRF Application during the Surgical Extraction of Third Molars on Healing and the Concentration of C-Reactive Protein. Pharmaceutics 2021, 13, 1471. https://doi.org/ $10.3390 /$ pharmaceutics13091471

Academic Editors: Ewa Kłodzińska and Marek Konop

Received: 15 August 2021

Accepted: 13 September 2021

Published: 15 September 2021

Publisher's Note: MDPI stays neutral with regard to jurisdictional claims in published maps and institutional affiliations.

Copyright: (c) 2021 by the authors. Licensee MDPI, Basel, Switzerland. This article is an open access article distributed under the terms and conditions of the Creative Commons Attribution (CC BY) license (https:/ / creativecommons.org/licenses/by/ $4.0 /)$.

\begin{abstract}
Extraction procedures for mandibular third molars are performed all over the world every day. Local inflammation resulting from surgery, and the pain that patients experience, often make it impossible to take up daily life activities, such as work or sports. Growth and anti-inflammatory factors, located in the fibrin network, have a positive effect on tissue-healing processes and should also reduce local inflammation. Advanced platelet-rich fibrin (A-PRF) applied locally influences such processes as: angiogenesis, osteogenesis and collagenogenesis. It also affects mesenchymal cell lines and anti- and pro-inflammatory mediators. Due to the autologous origin of the material, their use in guide bone regeneration (GBR) is more and more widespread in dentistry. The results of previous studies indicate that the use of A-PRF in the treatment area significantly reduces postoperative pain, while the formation of edema is not affected. C-reactive protein (CRP), which is an acute phase protein, appears in the blood as a consequence of inflammation. Due to the dynamics of changes in concentration of CRP, it is a protein that is sufficiently sensitive and is used in studies to monitor the tissue healing process. The effect of A-PRF application on CRP concentrations, before and after surgery, has not been investigated yet. The study was conducted on 60 generally healthy patients. A faster decrease of CRP levels was shown in patients who used A-PRF after the procedure. Additionally, it accelerated healing and reduced the occurrence of a dry socket close to 0 .
\end{abstract}

Keywords: wound dressing; healing process; tissue engineering; A-PRF; CRP; third molar

\section{Introduction}

Extraction procedures for mandibular third molars are performed all over the world every day. According to Rosa, $90 \%$ of the human population has third molars, of which approximately 33\% have at least one impacted tooth [1]. However, the data vary depending on the geographic region and population in which the research was conducted. According to Ayrancia's own research, and the data he analyzed, the percentage of impacted molars was estimated to be between 40.5 and $75.6 \%$ [2-6].

Local inflammation resulting from surgery, and the pain that patients experience often make it impossible to take up daily life activities, such as work or sports. In addition, there is also a psychological aspect, as patients with significant swelling of soft tissues avoid meeting people, so they often stay at home. The possibility of reducing unpleasant, subjective sensations is one of the goals of improving the operator's technique, as well as the reason for the search for new solutions and the use of new methods and materials in dentistry, such as fibrin preparations. Due to the action of growth and anti-inflammatory 
factors located in the fibrin network, there is a positive effect on tissue healing processes, and there should also be reduced local inflammation [7-9].

Advanced platelet-rich fibrin (A-PRF) is a second-generation blood derivative. It is distinguished from platelet-rich plasma by the formation of a fibrin scaffold in which there are stabilized platelets, which result in a slower release of growth factors [10-12]. The released factors include: VEGF (vascular endothelial growth factor), PDGF-AB (platelet derived growth factor $\mathrm{AB}$ ), TGF $\beta-1$ (transforming growth factor $\beta-1$ ), TSP-1 (trombospondin-1), IGF-I, IGF-II (insulin-like growth factors), EGF (epidermal growth factor), bFGF (basic fibroblast growth factor) $[13,14]$.

Thanks to these factors, when A-PRF is applied locally, it influences such processes as: angiogenesis, osteogenesis and collagenogenesis. It also affects mesenchymal cell lines and anti- and pro-inflammatory mediators $[15,16]$. The results of previous studies indicate that the use of A-PRF in the treatment area significantly reduces postoperative pain, while the formation of edema is not affected [17].

Thanks to growth factors, we can consider this procedure as guided bone regeneration (GBR), i.e., a procedure in which an appropriate "scaffold" is created for the regeneration of bone tissue in the patient's body. The purpose of the treatment is to support the regenerative processes of bone tissue and soft tissues [18]. It is extremely important, for clinical reasons, to minimize tissue loss after the extraction procedure. Thanks to this regeneration, it would be possible to insert an implant in the future. Due to the acceleration of regenerative processes, complications and hindering the healing processes occur less frequently [19-21].

Guided tissue regeneration is an ever-evolving field. Currently, many resorbable and nonresorbable materials are used in guided healing techniques.

The bone tissue in the masticatory system is extremely important. Bone tissue is constantly changing, as a result it can repair itself and adapt to new loads. The transformation of bone tissue involves the process of regeneration and modeling. Regeneration is the restoration of normal bone tissue at the site of its damage. Modeling, on the other hand, is the process of changing shape and size as a result of an acting stimulus.

Bone loss, as a result of tooth loss, is a significant clinical problem. Its possible consequences may be periodontal diseases of the neighboring teeth, and in extreme cases even jaw fracture.

Therefore, the healing of hard and soft tissues are considered an important step in treatment. As a result of studies at the microcellular level, platelets have been shown to play an extremely important role in wound healing. Patients undergoing extraction of the mandible third molar often experience severe pain, swelling and delayed healing. The healing process of the socket is composed of a number of biochemical, physiological and molecular sequences. These sequences are designed to restore tissue integrity and function.

Due to the possibility of side effects when using allogeneic materials, more and more hopes are being placed on autologous materials such as platelet-rich plasma and platelet-rich fibrin.

C-reactive protein (CRP), which is an acute phase protein, appears in the blood as a consequence of inflammation. It is produced under the influence of inflammatory cytokines in the liver, fat cells and arterial walls. Its concentration in the blood changes as a result of infection, inflammation, trauma, heart attack and during neoplastic diseases [22]. The CRP concentration is also influenced by sex, age, weight, the population that is being studied, medications taken, smoking and the method used for determination [23,24]. Due to the dynamics of changes in its concentration, it is a protein that is sufficiently sensitive and allows the monitoring of the tissue healing process [25-28]. Thanks to this, it is possible to use CRP as an indicator that is helpful not only in monitoring the course of treatment, but also in the early diagnosis of the inflammatory reaction [28-31]. The CRP concentration in a healthy person ranges from 0.1 to 3-9 $\mathrm{mg} / \mathrm{L}$ depending on the method of determination. The increase in CRP concentration in the blood is noticeable 4-6 h after the injury, and its highest concentration is recorded after 24-72 $\mathrm{h}$ [26]. Its concentration increases twice every $8 \mathrm{~h}$ after surgery and returns to a normal concentration after 7 days [29]. In the case 
of severe injuries, infections with gram-negative bacteria, characteristic of inflammation in the oral cavity, as well as as a result of neoplastic processes, the protein concentration may increase 1000-fold, reaching a value $>500 \mathrm{mg} / \mathrm{L}$. CRP production in hepatocytes is induced by cytokines released during tissue damage and inflammation, in particular IL-6 (interleukin-6) and TNF- $\alpha$ (tumor necrosis factor-alpha) [27,29].

Studies have already shown a relationship between the surgical extraction of impacted molars and the concentration of CRP in the blood before and after the procedure [30]. The literature also includes data on CRP protein concentration in dental patients presenting with acute inflammation, periodontal abscess, submucosal abscess and dry socket [31,32]. In 2017, Graziani et al. conducted a study in which they characterized differences in biomarkers of systemic inflammation, vascular function and metabolism (that is, looking at highly sensitive C-reactive protein, lipids, fibrinogen, oxidative stress and analysis of endothelial function) in patients undergoing surgical extraction of the third molar [33]. However, the effect of A-PRF application on CRP concentrations before and after surgery has not been investigated yet.

\section{Materials and Methods}

Single-center prospective studies were conducted on patients of the Department of Dental Surgery, Medical University of Warsaw. All research procedures were carried out in accordance with the Helsinki Declaration of 1975, revised in 2013. The study was approved by the Bioethics Committee of the Medical University of Warsaw 8.10.2018 (approval number: KB/190/2018).

\subsection{Experimental Groups}

Sixty patients were randomly distributed between control and study groups. Their assignment to the study and control group was made randomly using a coin toss, where the reverse was the test group, and the obverse meant the control group. The coin toss was made by the patients themselves, who did not know the assignment of groups depending on the side of the coin (Figure 1).

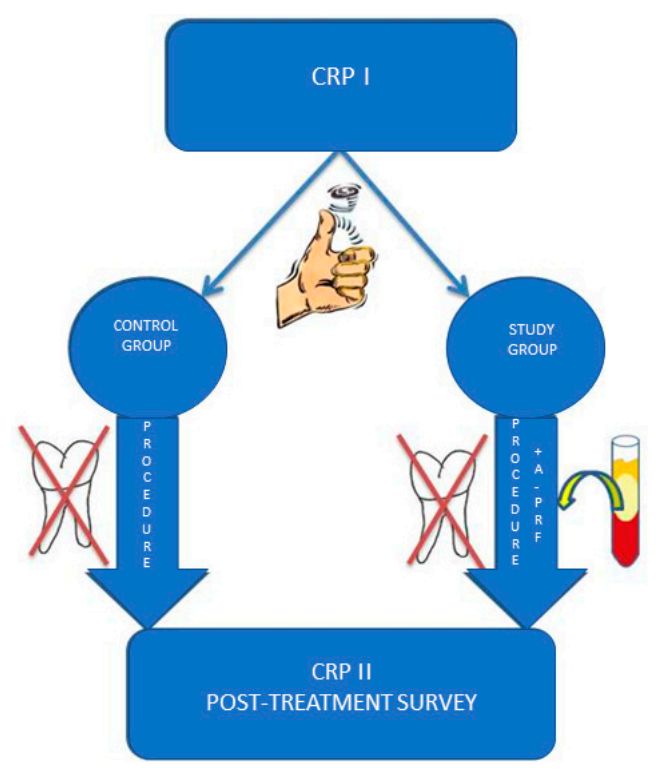

Figure 1. The scheme of the conducted study.

\subsection{Patient Selection}

The inclusion criteria were designed to include patients between 18 and 40 years of age, in good general condition, requiring extraction of a partially impacted mandibular third molar. The study included only patients whose tooth needing extraction was in the mesio-angular position according to Winter and class II B according to Pell and Gregory 
(the crown of the third molar is covered by one-half of the front edge of the mandibular arm, the occlusal plane of the impacted molar tooth). The third molar is between the occlusal plane of the adjacent tooth and the neck of the adjacent tooth.

Patients were excluded from the study due to: poor oral hygiene, smoking, general diseases, diseases and treatment influencing blood biochemical parameters, pregnancy, breastfeeding, genetic diseases and craniofacial congenital malformations, people with advanced periodontal disease, people with multiple missing teeth, people with a BMI > 30, those taking anti-inflammatory drugs or if they had any other contraindications for oral surgery.

The clinical data of the patients are presented in the table. The gender distribution in the A-PRF group included 19 men (63.3\%) and 11 women (36.6\%). The mean age was 25.91 years for women and 25.42 for men. For the study group of 19 men $(63.3 \%)$ and 11 women $(36.6 \%)$, respectively, the mean age was 22.64 years for women and 25.58 for men (Table 1).

Table 1. Age, number and sex of patients in particular groups. Data are presented as abundance or mean \pm standard deviation (SD); f-female; $\mathrm{m}$-male.

\begin{tabular}{ccc}
\hline Lables & Study Group & Control Group \\
\hline number of participants & 30 & 30 \\
\hline \multirow{2}{*}{ sex } & f: $1 ;$ & f: $11 ;$ \\
& m: 19 & m: 19 \\
\hline \multirow{2}{*}{ age (mean) } & f: $25.91 \pm 5.61 ;$ & f: $22.64 \pm 2.46 ;$ \\
& m: $25.42 \pm 3.55$ & m: $26.58 \pm 3.80$ \\
\hline
\end{tabular}

\subsection{PRF Management}

Before the procedure, blood was collected from a radial vein of those people in the study group using $4 \mathrm{~A}-\mathrm{X}$ BY CHOUKROUN $10 \mathrm{~mL}$ tubes, then the original protocol proposed by Dr. Joseph Choukroun was applied. The blood was centrifuged in the PRF DUO QUATTRO centrifuge at $1500 \mathrm{rpm} /$ for $14 \mathrm{~min}$. After centrifugation, the obtained clot was collected from the tube, then separated from the plate mass and placed in a special PRF BOX (Figure 2). The two clots were left on a perforated clamp plate to drain and obtain the A-PRF membrane, the other two clots were placed in clamp containers for fibrin plugs.

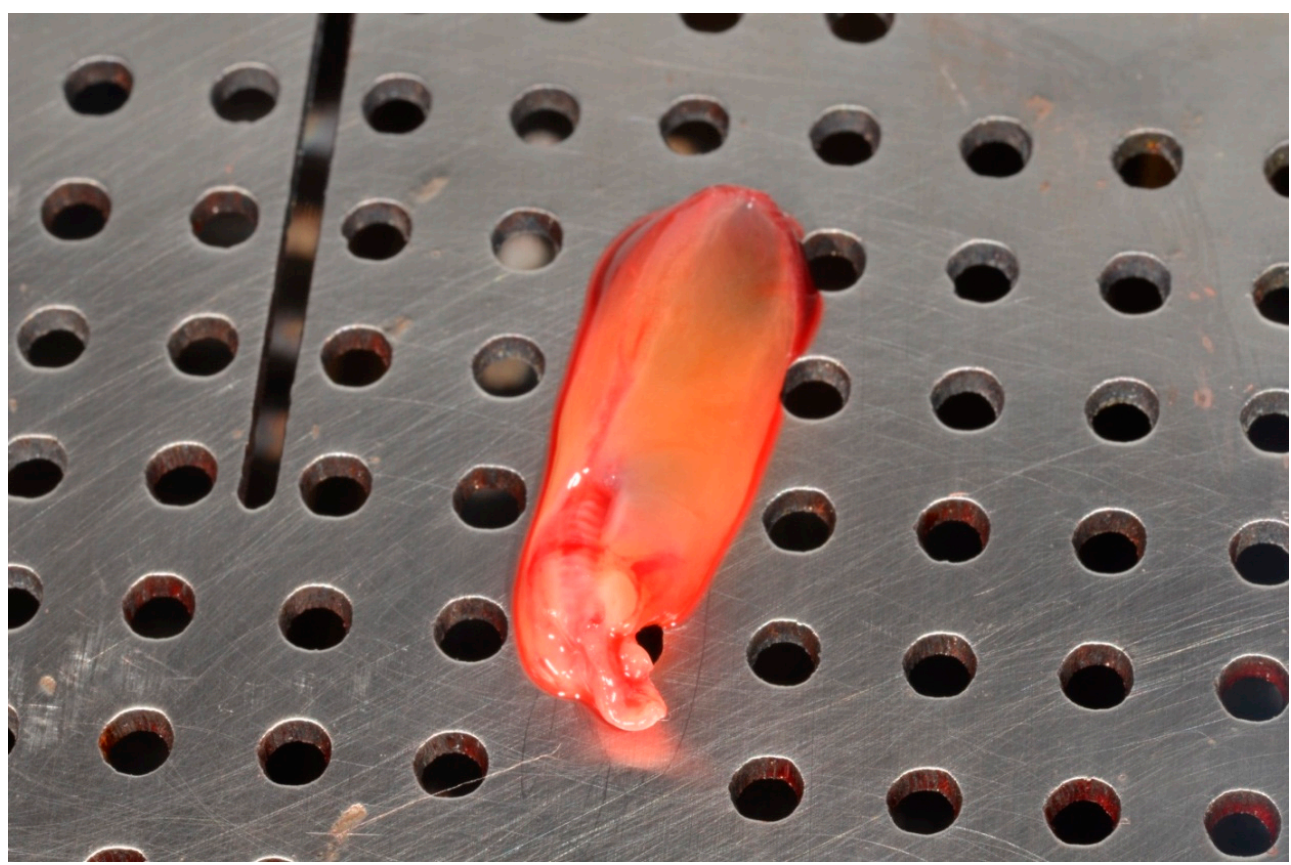

Figure 2. A-PRF clot on a perforated plate of the PRF-BOX system. 


\subsection{Surgical Procedures and Intrasurgical Measurements}

Before the procedure, blood was drawn from all patients to determine the concentration of CRP. Tooth extraction was performed under local anesthesia (Lignocainum $2 \%$ c. Noradrenalino $0.00125 \%$ ). In all patients, the muco-periosteal envelope flap was incised and detached from the area around the teeth, 36-38 or 46-48. Then, an osteotomy was performed around the tooth crown using a rubella handpiece drill. The treatments were performed by the same operator. During the procedure, the time of the procedure was measured-all procedures were completed within 30-40 min. After the tooth extraction was performed in the study group, the previously prepared A-PRF preparation was placed in the alveolus in the form of two fibrin plugs and two membranes. For patients in the control group, placement of the preparation in the socket was simulated. Surgical wounds were fitted with single knotted sutures using Safil 3.0 absorbable synthetic sutures. Postoperatively, patients from both groups were treated with the same pharmacotherapy, $1 \mathrm{~g}$ of amoxicillin -1 tablet every $12 \mathrm{~h}$-and non-steroidal anti-inflammatory painkillers (NSAIDs). Sutures were removed 7 days after surgery, and patients were re-tested for CRP concentrations.

\subsection{Blood Test Methodology}

The material for laboratory tests was venous blood, collected from a radial vein using the Biomedico collection kit $(21 \mathrm{GX} 3 / 4)$. Blood was collected in the morning between 8:00 and 10:00, after rest, in a sitting position, having eaten a light breakfast. BD Vacutainer SST TM II Advance $8.5 \mathrm{~mL}$ tubes with silica gel as a clot activator were used. The blood tubes were centrifuged according to the manufacturer's recommendations, 1300-2000 $g$ for 10 min. Patients' blood was tested in the Diagnostic Laboratory of the Infant Jesus Hospital in Warsaw.

\subsection{Methodology of Blood Biochemical Testing}

The Hs-CRP test (high sensitivity C-reactive protein) was used for the biochemical test-determination of the concentration of CRP in blood serum-a test of high sensitivity, detecting changes in the concentration of CRP protein in undiluted samples of human serum, plasma or homogenized tissues. It allows you to precisely determine even a low concentration of CRP. It is a quantitative sandwich ELISA (enzyme linked immunosorbent assay) test, i.e., a double binding test. It involves the binding of an antigen between two layers of antibodies. The sensitivity of this test is $0.1 \mu \mathrm{g} / \mathrm{mL}$, and the detection range is $0.25 \mu \mathrm{g} / \mathrm{mL}$ to approximately $8-10 \mu \mathrm{g} / \mathrm{mL}$. The concentration of C-reactive protein was determined immediately before the procedure (CRP I) and again 7 days after the procedure (CRP II). Additionally, the difference between the two measurements ( $\triangle \mathrm{CRP}$ ) was also determined.

The rate of $\triangle \mathrm{CRP}$ was evaluated as the difference between CRP I and CRP II and expressed as a number using the formula: $\triangle \mathrm{CRP}=\mathrm{CRP}$ II $-\mathrm{CRP}$ I

Based on the clinical examination and subjective feelings of the patient, the occurrence of a complication, i.e., difficult healing in the form of a dry socket, was also assessed. The rate of $\triangle \mathrm{CRP}$ was evaluated as the difference between CRP I and CRP II and expressed as a number using the formula:

$$
\triangle \mathrm{CRP}=\mathrm{CRP} \text { II }-\mathrm{CRP} I
$$

\subsection{Control Day}

Seven days after the surgery, the sutures were removed and a short postoperative questionnaire was completed regarding the presence or absence of signs of local inflammation based on a clinical examination:

1. swelling

2. pain

3. subjective trismus

4. redness at the treatment site 


\section{5. dry mouth \\ 6. burning}

\subsection{Statistical Analysis}

The conducted studies were randomized, prospective and screening studies. During the research work, the results obtained in both women and men were analyzed. In the statistical analysis, same-sex groups were not distinguished. The obtained test results were subjected to statistical analysis, taking into account the parameters of descriptive statistics: mean values, standard deviations as well as minimum and maximum values for measurable variables in the test and control groups. In order to compare the parameters consistent with a normal distribution, the t-student test was used, the remaining data were statistically analyzed using non-parametric methods-U Mann-Whitney. Statistical significance was assumed as $p<0.05$. Statistica 13.3 (StatSoft) was used for the analysis.

\section{Results}

\section{1. $C R P$}

The study looked at data on age, gender, CRP levels, and its effect on symptoms of inflammation. The results of individual studies in both groups are presented in Table 2.

Table 2. Data of the procedures: $\triangle \mathrm{CRP}$-difference in CRP concentration between CRP II and CRP I.

\begin{tabular}{|c|c|c|c|c|c|c|}
\hline Group & Patient & Age & Sex & CRP I & CRP II & $\Delta \mathrm{CRP}$ \\
\hline \multirow{30}{*}{ Study } & 1 & 26 & M & 0.40 & 0.20 & -0.20 \\
\hline & 2 & 20 & M & 0.44 & 2.68 & 2.24 \\
\hline & 3 & 36 & K & 0.51 & 0.14 & -0.37 \\
\hline & 4 & 23 & M & 1.50 & 2.29 & 0.79 \\
\hline & 5 & 26 & M & 3.26 & 1.38 & -1.88 \\
\hline & 6 & 36 & K & 1.72 & 1.99 & 0.27 \\
\hline & 7 & 23 & M & 1.82 & 1.96 & 0.14 \\
\hline & 8 & 22 & $\mathrm{~K}$ & 1.30 & 1.14 & -0.16 \\
\hline & 9 & 26 & M & 2.10 & 0.90 & -1.20 \\
\hline & 10 & 27 & K & 4.98 & 1.50 & -3.48 \\
\hline & 11 & 26 & M & 0.30 & 1.14 & 0.84 \\
\hline & 12 & 22 & $\mathrm{M}$ & 1.22 & 3.91 & 2.69 \\
\hline & 13 & 27 & K & 0.19 & 2.20 & 2.01 \\
\hline & 14 & 26 & M & 3.30 & 1.34 & -1.96 \\
\hline & 15 & 32 & M & 4.00 & 2.50 & -1.50 \\
\hline & 16 & 24 & K & 1.50 & 1.00 & -0.50 \\
\hline & 17 & 20 & $\mathrm{~K}$ & 0.12 & 2.13 & 2.01 \\
\hline & 18 & 22 & K & 1.50 & 1.10 & -0.40 \\
\hline & 19 & 20 & K & 0.15 & 2.10 & 1.95 \\
\hline & 20 & 33 & M & 3.90 & 2.30 & -1.60 \\
\hline & 21 & 22 & M & 3.10 & 1.20 & -1.90 \\
\hline & 22 & 27 & K & 4.96 & 1.54 & -3.42 \\
\hline & 23 & 25 & M & 0.37 & 0.26 & -0.11 \\
\hline & 24 & 27 & M & 2.09 & 0.94 & -1.15 \\
\hline & 25 & 21 & M & 0.35 & 2.66 & 2.31 \\
\hline & 26 & 31 & M & 4.19 & 2.54 & -1.65 \\
\hline & 27 & 24 & K & 1.25 & 1.05 & -0.20 \\
\hline & 28 & 26 & $\mathrm{M}$ & 1.30 & 1.10 & -0.20 \\
\hline & 29 & 23 & $\mathrm{M}$ & 1.15 & 3.80 & 2.65 \\
\hline & 30 & 25 & M & 2.15 & 0.97 & -1.18 \\
\hline
\end{tabular}


Table 2. Cont.

\begin{tabular}{|c|c|c|c|c|c|c|}
\hline Group & Patient & Age & Sex & CRP I & CRP II & $\Delta \mathrm{CRP}$ \\
\hline \multirow{30}{*}{ Control } & 1 & 25 & $\mathrm{~K}$ & 4.95 & 7.50 & 2.55 \\
\hline & 2 & 34 & M & 0.50 & 4.70 & 4.20 \\
\hline & 3 & 25 & M & 0.30 & 0.90 & 0.60 \\
\hline & 4 & 27 & M & 2.30 & 1.70 & -0.60 \\
\hline & 5 & 26 & $\mathrm{~K}$ & 1.34 & 6.30 & 4.96 \\
\hline & 6 & 20 & $\mathrm{~K}$ & 0.10 & 0.31 & 0.21 \\
\hline & 7 & 26 & M & 0.75 & 2.10 & 1.35 \\
\hline & 8 & 26 & M & 2.00 & 1.60 & -0.40 \\
\hline & 9 & 20 & K & 0.01 & 0.21 & 0.20 \\
\hline & 10 & 23 & $\mathrm{~K}$ & 0.34 & 8.17 & 7.83 \\
\hline & 11 & 26 & M & 2.12 & 1.94 & -0.18 \\
\hline & 12 & 33 & $\mathrm{M}$ & 0.32 & 4.83 & 4.51 \\
\hline & 13 & 37 & M & 0.60 & 5.03 & 4.43 \\
\hline & 14 & 24 & M & 1.34 & 2.27 & 0.93 \\
\hline & 15 & 25 & $\mathrm{~K}$ & 4.95 & 7.50 & 2.55 \\
\hline & 16 & 24 & $\mathrm{~K}$ & 0.70 & 8.00 & 7.30 \\
\hline & 17 & 26 & M & 0.50 & 2.00 & 1.50 \\
\hline & 18 & 25 & M & 0.15 & 0.95 & 0.80 \\
\hline & 19 & 25 & M & 0.50 & 1.30 & 0.80 \\
\hline & 20 & 23 & M & 1.34 & 2.27 & 0.93 \\
\hline & 21 & 21 & $\mathrm{~K}$ & 1.51 & 2.49 & 0.98 \\
\hline & 22 & 25 & K & 3.95 & 6.40 & 2.45 \\
\hline & 23 & 25 & $\mathrm{M}$ & 0.20 & 0.90 & 0.70 \\
\hline & 24 & 25 & M & 0.30 & 0.90 & 0.60 \\
\hline & 25 & 25 & M & 0.29 & 0.80 & 0.51 \\
\hline & 26 & 24 & M & 1.20 & 2.07 & 0.87 \\
\hline & 27 & 26 & M & 0.45 & 2.15 & 1.70 \\
\hline & 28 & 20 & $\mathrm{~K}$ & 0.05 & 0.35 & 0.30 \\
\hline & 29 & 23 & $\mathrm{M}$ & 2.35 & 3.25 & 0.90 \\
\hline & 30 & 20 & $\mathrm{~K}$ & 0.30 & 0.61 & 0.31 \\
\hline
\end{tabular}

The performed statistical analysis showed that the mean value of CRP II and the difference in CRP $\Delta$ in the control group $(2.98 \pm 2.54$ and $1.79 \pm 2.15$, respectively) were significantly higher than in the study group and this was statistically significant $(1.66 \pm 0.93 \mathrm{mg} / \mathrm{L}$ and $0.17 \pm 1.7 \mathrm{mg} / \mathrm{L})$ (Table 3$)$.

Table 3. Descriptive statistics of CRP I, CRP II and CRP $\Delta$ protein concentration in the study and control groups. $n$-number of patients; SD-standard deviation, $p$ TEST-power of test.

\begin{tabular}{ccccccccc}
\hline & Group & $\boldsymbol{n}$ & Mean & Median & Minimum & Maximum & SD & $p$ TEST \\
\hline \multirow{2}{*}{ CRPI } & Study & 30 & 1.84 & 1.5 & 0.12 & 4.98 & 1.48 & \multirow{2}{*}{0.083} \\
& Control & 30 & 1.19 & 0.55 & 0.01 & 4.95 & 1.35 & \\
\hline \multirow{2}{*}{ CRP II } & Study & 30 & 1.66 & 1.44 & 0.14 & 3.91 & 0.93 & \multirow{2}{*}{0.01} \\
& Control & 30 & 2.98 & 2.08 & 0.21 & 8.18 & 2.54 & \\
\hline \multirow{2}{*}{ CRP $\Delta$} & Study & 30 & 0.17 & -0.2 & -3.48 & 2.69 & 1.70 & \multirow{2}{*}{0.001} \\
& Control & 30 & 1.79 & 0.915 & 0.60 & 7.83 & 2.15 & \\
\hline
\end{tabular}

\subsection{Postoperative Survey}

During the inspection, the doctor also assessed features that may indicate the presence of local inflammation. The results of clinical trials and their analysis are presented in Table 4; Table 5 and Figure 3. 
Table 4. Occurrence of symptoms of inflammation on day seven, postoperative. Data presented as the number and percentage of a given group.

\begin{tabular}{|c|c|c|c|c|c|c|c|c|c|c|c|c|c|c|}
\hline \multirow{2}{*}{$\begin{array}{c}\text { Patients Who } \\
\text { Have } \\
\text { Occurred }\end{array}$} & \multicolumn{2}{|c|}{ Swelling } & \multicolumn{2}{|c|}{ Pain } & \multicolumn{2}{|c|}{$\begin{array}{l}\text { Subjective } \\
\text { Trismus }\end{array}$} & \multicolumn{2}{|c|}{$\begin{array}{l}\text { Redness at the } \\
\text { Treatment Site }\end{array}$} & \multicolumn{2}{|c|}{ Dry Mouth } & \multicolumn{2}{|c|}{ Burning } & \multicolumn{2}{|c|}{ Dry Socket } \\
\hline & $\mathbf{N}$ & $\%$ & $\mathbf{N}$ & $\%$ & $\mathbf{N}$ & $\%$ & $\mathbf{N}$ & $\%$ & $\mathbf{N}$ & $\%$ & $\mathbf{N}$ & $\%$ & $\mathbf{N}$ & $\%$ \\
\hline Study Group & 3 & 10 & 0 & 0 & 0 & 0 & 0 & 0 & 0 & 0 & 0 & 0 & 3 & 10 \\
\hline Control Group & 16 & $53.33 \%$ & 27 & $90 \%$ & 9 & $30 \%$ & 12 & $40 \%$ & 6 & $20 \%$ & 3 & $10 \%$ & 15 & $50 \%$ \\
\hline
\end{tabular}

Table 5. Descriptive statistics of inflammatory symptoms occurring on day seven, postoperative, in the study and control groups. $n$ - number of patients; SD-standard deviation, $p$ TEST-power of test.

\begin{tabular}{|c|c|c|c|c|c|c|c|c|}
\hline & Group & $n$ & Mean & Median & Minimum & Maximum & SD & $p$ Test \\
\hline \multirow{2}{*}{ Swelling } & STUDY & 30 & 0.1 & 0 & 0 & 1 & 0.31 & \multirow{2}{*}{0.004} \\
\hline & CONTROL & 30 & 0.53 & 1 & 0 & 1 & 0.51 & \\
\hline \multirow{2}{*}{ Pain } & STUDY & 30 & 0 & 0 & 0 & 0 & 0 & \multirow{2}{*}{0.000} \\
\hline & CONTROL & 30 & 0.9 & 1 & 0 & 1 & 0.30 & \\
\hline \multirow{2}{*}{ Subjective trismus } & STUDY & 30 & 0 & 0 & 0 & 0 & 0 & \multirow{2}{*}{0.047} \\
\hline & CONTROL & 30 & 0.3 & 0 & 0 & 1 & 0.47 & \\
\hline \multirow{2}{*}{$\begin{array}{l}\text { Redness at the } \\
\text { treatment side }\end{array}$} & STUDY & 30 & 0 & 0 & 0 & 0 & 0 & \multirow{2}{*}{0.008} \\
\hline & CONTROL & 30 & 0.4 & 0 & 0 & 1 & 0.50 & \\
\hline \multirow{2}{*}{ Dry mouth } & STUDY & 30 & 0 & 0 & 0 & 0 & 0 & \multirow{2}{*}{0.185768} \\
\hline & CONTROL & 30 & 0.2 & 0 & 0 & 1 & 0.41 & \\
\hline \multirow{2}{*}{ Burning } & STUDY & 30 & 0 & 0 & 0 & 0 & 0 & \multirow{2}{*}{0.510598} \\
\hline & CONTROL & 30 & 0.1 & 0 & 0 & 1 & 0.30 & \\
\hline
\end{tabular}

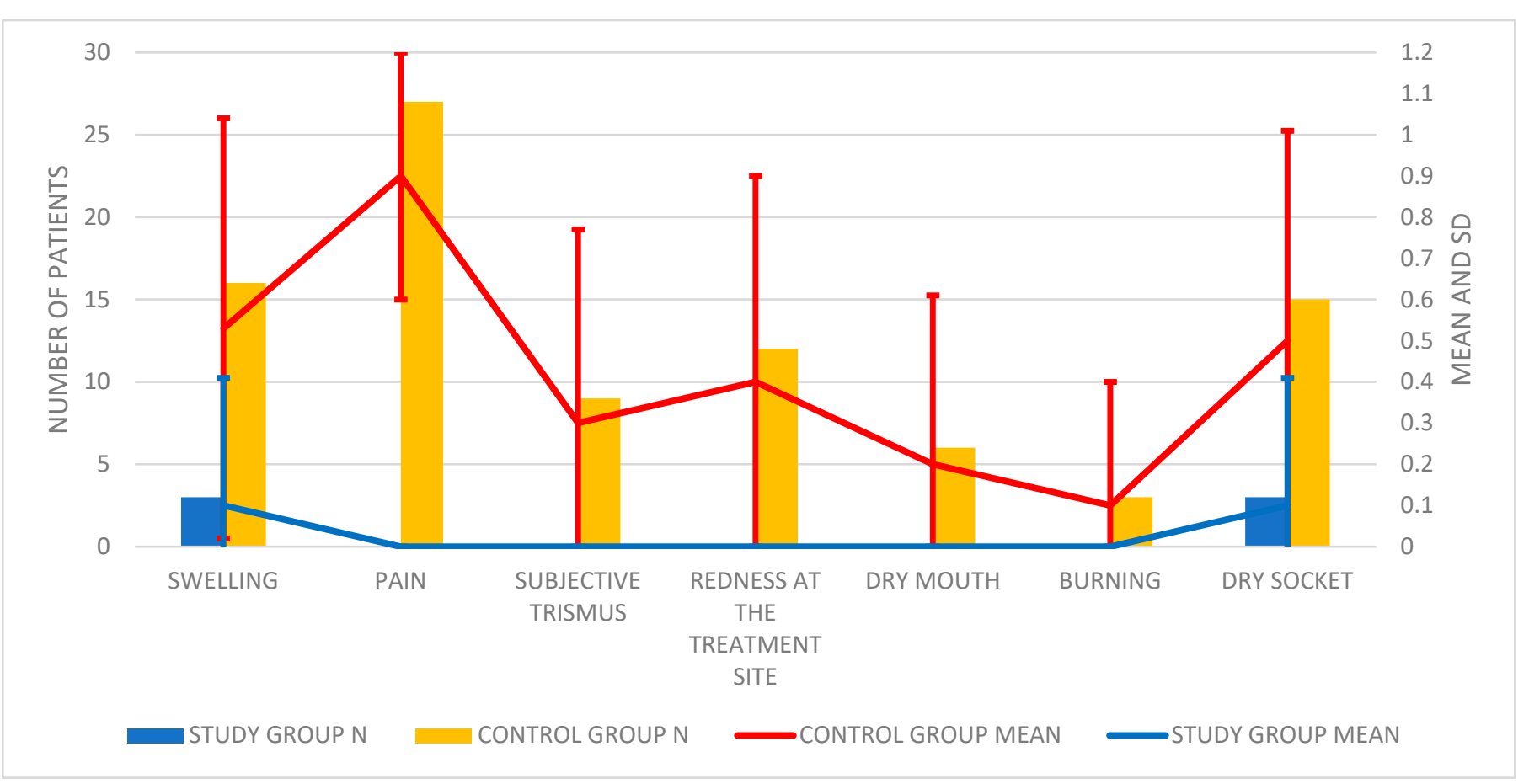

Figure 3. Histogram showing the number of symptoms of inflammation and complications in the form of a dry socket.

On the basis of the obtained results, it was found that the difference in the occurrence of swelling between the groups was statistically significant. The average frequency of swelling in the study group was $0.1 \pm 0.31$, while in the control group it was $0.53 \pm 0.51$. 
The difference in the occurrence of pain, trismus and redness on the seventh day, postoperative, was also statistically significant. In the study group, the above features were not found $(0 ; 0 ; 0$, respectively), and in the control group, they were $0.9 \pm 0.3 ; 0.3 \pm 0.47$; $0.4 \pm 0.5$.

There were no statistically significant differences in the occurrence of dry mouth and burning in the mouth between the study and control groups.

During the follow-up examination, the incidence of post-extraction complication was also determined, i.e., local inflammation in the form of a dry socket (Table 6).

Table 6. Descriptive statistics of the occurrence of a complication in the form of a dry socket on the day of the inspection in the study group and in the control group. $n$-number of patients; SD-standard deviation; $p$ TEST-power of test.

\begin{tabular}{cccccccccc}
\hline & Group & $n$ & Mean & Median & Minimum & Maximum & SD & $p$ TEST \\
\hline \multirow{2}{*}{ Dry Socket } & Study & 30 & 0.1 & 0 & 0 & 1 & 0.31 & 0.007959 \\
\cline { 2 - 10 } & Control & 30 & 0.5 & 0.5 & 0 & 1 & 0.51 & \\
\hline
\end{tabular}

In patients from the control group, the occurrence of dry socket $0.5 \pm 0.51$ was significantly more frequent statistically compared to the study group $0.1 \pm 0.31$.

\section{Discussion}

The concentration of CRP protein as a marker of inflammation is closely related to the healing process of postoperative tissues. It is dependent on many factors, and blood levels are affected by inflammation. A standard test measures a much wider range of CRP concentrations, but is less sensitive in the lower ranges, and the high-sensitivity CRP (hs-CRP) test detects lower concentrations of protein more accurately (it is more sensitive), making it more useful than the standard CRP test in the evaluation of the treatment process. Depending on the type of high-sensitivity test used, there is a difference in accuracy, which has been confirmed by numerous comparative studies [34-37].

It takes about 7 days for CRP to return to normal concentration levels [29]. However, from the work of Ceiod, the increased concentration may persist for up to 2 months [38]. The author's own research showed statistically significant differences in the tissue regeneration process between the study group and the control group. An analysis of the concentration of CRP protein before and 7 days after the procedure showed that in both groups of patients, its concentration was lower than $10 \mu \mathrm{g} / \mathrm{mL}$, so it was within the normal range. However, the mean values of CRP II protein concentration indicated slightly better regenerative processes in the study group as compared to the control group.

The faster return to normal concentration levels of patients treated with A-PRF is a result of better tissue healing. A-PRF is a clot that not only releases growth factors, but also mechanically covers the bone tissue, isolating it from the oral cavity environment, and thus saliva, which contains millions of bacteria [39]. Thanks to its antibacterial effect, it is not possible to colonize the clot. However, Al-Hamed states that PRF has no effect on the infection of the socket (understood as a socket with purulent exudate), reddening of the area and increased body temperature [40]. Furthermore, these findings were replicated in our own research and that conducted by Fujioka-Kobayashi et al. A literature review showed that the use of A-PRF significantly reduced the percentage of dry socket [41]. Thanks to anti-inflammatory factors, the body's response to an extraction injury is also reduced. By reducing the secretion of pro-inflammatory factors in the treatment area, the concentration of CRP protein in the blood is also lower. Moreover, the presence of white blood cells in A-PRF inhibits the growth of bacteria.

There have been numerous research papers describing the postoperative symptoms and healing process in patients undergoing surgical removal of the third molar in the mandible [42-55]. One of the causes of persistent pain after extraction of the third molar is the occurrence of post-extraction local inflammation in the form of a dry socket. It is the most common complication and its frequency is determined to be from $7 \%$ to $35 \%$ [56-60]. 
There are many publications on the etiology and techniques of dry socket treatment in the literature [60-64]. A dry socket is local inflammation of the bone resulting from a clot not covering the bone tissue. The pain is felt until the connective tissue is granulated and the bone tissue is "covered". A dry socket is diagnosed as a continuous throbbing postoperative pain in the extraction area that is not adequately relieved by painkillers. The authors' own research shows that in the patient study group, they developed a dry socket $40 \%$ less often than in the control group. Only $10 \%$ of patients in this group showed the features of a dry socket. A statistically significant difference between the two groups correlates with the results obtained by other researchers. According to Al-Hamed, A-PRF significantly reduced the incidence of a dry socket complication compared to the control group [40]. Hoaglin's studies also document a reduction in the incidence of dry socket by $9.5 \%$ in the control group and $1 \%$ in the group with PRF [65]. As stated in the meta-analysis prepared by Al-Hamed, the most significant and reliable results are those obtained by Eshghpour [66]. However, Asutay's research did not confirm a statistically significant difference between the groups [67]. The beneficial effects of using A-PRF result from the presence of the many growth factors in it. These factors stimulate cellular mitosis and differentiation, increase collagen production, recruit leukocytes and other cells to the surgical site and initiate vessel growth. This promotes the healing of soft and hard tissues and at the same time intensifies angiogenesis. Moreover, the presence of white blood cells in A-PRF inhibits the growth of bacteria. Similar results were obtained in 2007 by Rutkowski in his research on the use of PRP placed in the extraction socket [68].

Also noteworthy is the study by Ratiu et al., in which they assessed the properties of various commercially available resorbable collagen membranes in the guided regeneration of bones after the addition of growth factor-rich plasma (PRGF) [69]. The structural and morphological features of three different commercial collagen membranes were tested. It was found that features such as porosity, fiber density, and surface topography can influence the mechanical behavior and performance of the membranes. Using spectroscopy, it was shown that the collagen matrix can act as a natural environment for supplying growth factors. The mechanical properties of the membranes were tested before and after soaking in PRGF. Tests showed that PRGF-modified membranes degraded more slowly compared to native membranes.

\section{Conclusions}

It should be noted that the concentration of reactive protein $C$ in the peripheral blood, 7 days after the surgical extraction of the impacted tooth, is lower in patients who received A-PRF blood product intra-operatively. The decrease in CRP concentration proves that dental problems affect the general health condition of patients. Even a slight inflammation associated with the difficult eruption of third wisdom teeth causes a slight increase in CRP protein. The A-PRF preparation, on the other hand, allows for a faster reduction of CRP concentration after the procedure. In addition, A-PRF reduces the occurrence of symptoms indicative of local inflammation and significantly reduces the incidence of postoperative complication in the form of a dry socket.

Author Contributions: Conceptualization, J.M.N.; A.W., M.R.C.; methodology, J.M.N.; software, S.S., M.R.; validation, J.M.N., S.S., M.R.; formal analysis, J.M.N.; investigation, J.M.N.; resources, J.M.N.; data curation, J.M.N.; writing—original draft preparation, J.M.N., M.R.C.; writing—review and editing, S.S., M.R., A.W., K.J.F.; visualization, M.R.; supervision, A.W., M.R.C., K.J.F.; project administration, J.M.N., M.R.C.; funding acquisition, A.W. All authors have read and agreed to the published version of the manuscript.

Funding: This research received no external funding.

Institutional Review Board Statement: The study was conducted according to the guidelines of the Declaration of Helsinki and approved by the Bioethics Committee of the Medical University of Warsaw (approval number: KB/190/2018). 
Informed Consent Statement: Informed consent was obtained from all subjects involved in the study.

Data Availability Statement: Not applicable.

Conflicts of Interest: The authors declare no conflict of interest.

\section{References}

1. Rosa, A.L.; Carneiro, M.G.; Lavrador, M.A.; Novaes, A.B. Influence of flap design on periodontal healing of second molars after extraction of impacted mandibular third molars. Oral Surg. Oral Med. Oral Pathol. Oral Radiol. Endodontol. 2002, 93, 404-407. [CrossRef]

2. Ayranci, F.; Omezli, M.M.; Sivrikaya, E.C.; Rastgeldi, Z.O. Prevalence of Impacted Wisdom Teeth in Middle Black Sea Population. J. Clin. Exp. Investig. 2017, 8, 58-61. [CrossRef]

3. Nejat, A.; Shamsabadi, R.M.; Rezaei, N.; Eshghpour, M.; Nezadi, A.; Moradi, A. Pattern of mandibular third molar impaction: A cross-sectional study in northeast of Iran. Niger. J. Clin. Pract. 2014, 17, 673-677. [CrossRef] [PubMed]

4. Mansimranjit Kaur, U.; Vishnu, K.; Samrat, G. Prevalence and Pattern of Third Molar Impaction among Residents of District Panchkula, India. Int. Healthc. Res. J. 2018, 2, 41-44. [CrossRef]

5. Kumar Pillai, A.; Thomas, S.; Paul, G.; Singh, S.K.; Moghe, S. Incidence of impacted third molars: A radiographic study in People's Hospital, Bhopal, India. J. Oral Biol. Craniofacial Res. 2014, 4, 76-81. [CrossRef]

6. Bayoumi, A.M.; Baabdullah, R.M.; Bokhari, A.F.; Nadershah, M. The Prevalence Rate of Third Molar Impaction among Jeddah Population. Int. J. Dent. Oral Heal. 2016, 2, 1-4. [CrossRef]

7. Ratajczak, J.; Vangansewinkel, T.; Gervois, P.; Merckx, G.; Hilkens, P.; Quirynen, M.; Lambrichts, I.; Bronckaers, A. Angiogenic Properties of 'Leukocyte- and Platelet-Rich Fibrin'. Sci Rep. 2018, 8, 14632. [CrossRef] [PubMed]

8. Strauss, F.-J.; Nasirzade, J.; Kargarpoor, Z.; Stähli, A.; Gruber, R. Effect of platelet-rich fibrin on cell proliferation, migration, differentiation, inflammation, and osteoclastogenesis: A systematic review of in vitro studies. Clin. Oral Investig. 2019, 24, 569-584. [CrossRef]

9. Kim, J.; Ha, Y.; Kang, N.H. Effects of Growth Factors from Platelet-Rich Fibrin on the Bone Regeneration. J. Craniofacial Surg. 2017, 28, 860-865. [CrossRef] [PubMed]

10. Lundquist, R.; Dziegiel, M.H.; Ågren, M.S. Bioactivity and stability of endogenous fibrogenic factors in platelet-rich fibrin. Wound Repair Regen. 2008, 16, 356-363. [CrossRef]

11. Schaller, B.; Miron, R.J.; Kobayashi, M.; Sawada, K.; Sculean, A.; Kobayashi, E.; Flückiger, L. Comparative release of growth factors from PRP, PRF, and advanced-PRF. Clin. Oral Investig. 2016, 20, 2353-2360. [CrossRef]

12. Kobayashi, M.; Kawase, T.; Horimizu, M.; Okuda, K.; Wolff, L.F.; Yoshie, H. A proposed protocol for the standardized preparation of PRF membranes for clinical use. Biologicals 2012, 40, 323-329. [CrossRef]

13. Nishimoto, S.; Fujita, K.; Sotsuka, Y.; Kinoshita, M.; Fujiwara, T.; Kawai, K.; Kakibuchi, M. Growth Factor Measurement and Histological Analysis in Platelet Rich Fibrin: A Pilot Study. J. Maxillofac. Oral Surg. 2015, 14, 907-913. [CrossRef] [PubMed]

14. Masuki, H.; Okudera, T.; Watanabe, T.; Suzuki, M.; Nishiyama, K.; Okudera, H.; Nakata, K.; Uematsu, K.; Su, C.-Y.; Kawase, T. Growth factor and pro-inflammatory cytokine contents in platelet-rich plasma (PRP), plasma rich in growth factors (PRGF), advanced platelet-rich fibrin (A-PRF), and concentrated growth factors (CGF). Int. J. Implant. Dent. 2016, 2, 1-6. [CrossRef]

15. Dohan Ehrenfest, D.M.; Diss, A.; Odin, G.; Doglioli, P.; Hippolyte, M.P.; Charrier, J.B. In vitro effects of Choukroun's PRF (platelet-rich fibrin) on human gingival fibroblasts, dermal prekeratinocytes, preadipocytes, and maxillofacial osteoblasts in primary cultures. Oral Surg. Oral Med. Oral Pathol. Oral Radiol. Endodontol. 2009, 108, 341-352. [CrossRef]

16. He, L.; Lin, Y.; Hu, X.; Zhang, Y.; Wu, H. A comparative study of platelet-rich fibrin (PRF) and platelet-rich plasma (PRP) on the effect of proliferation and differentiation of rat osteoblasts in vitro. Oral Surg. Oral Med. Oral Pathol. Oral Radiol. Endodontol. 2009, 108, 707-713. [CrossRef]

17. Caymaz, M.G.; O Uyanik, L. Comparison of the effect of advanced platelet-rich fibrin and leukocyte- and platelet-rich fibrin on outcomes after removal of impacted mandibular third molar: A randomized split-mouth study. Niger. J. Clin. Pract. 2019, 22, 546-552. [CrossRef] [PubMed]

18. Knapen, M.; Gheldof, D.; Drion, P.; Layrolle, P.; Rompen, E.; Lambert, F. Effect of Leukocyte- and Platelet-Rich Fibrin (L-PRF) on Bone Regeneration: A Study in Rabbits. Clin. Implant. Dent. Relat. Res. 2013, 17, e143-e152. [CrossRef] [PubMed]

19. Castro, A.B.; Meschi, N.; Temmerman, A.; Pinto, N.; Lambrechts, P.; Teughels, W.; Quirynen, M. Regenerative potential of leucocyte- and platelet-rich fibrin. Part B: Sinus floor elevation, alveolar ridge preservation and implant therapy. A systematic review. J. Clin. Periodontol. 2016, 44, 225-234. [CrossRef] [PubMed]

20. Wang, X.; Zhang, Y.; Choukroun, J.; Ghanaati, S.; Miron, R.J. Effects of an injectable platelet-rich fibrin on osteoblast behavior and bone tissue formation in comparison to platelet-rich plasma. Platelets 2018, 29, 48-55. [CrossRef]

21. Miron, R.J.; Zucchelli, G.; Pikos, M.A.; Salama, M.; Lee, S.; Guillemette, V.; Fujioka-Kobayashi, M.; Bishara, M.; Zhang, Y.; Wang, H.-L.; et al. Use of platelet-rich fibrin in regenerative dentistry: A systematic review. Clin. Oral Investig. 2017, 21, 1913-1927. [CrossRef]

22. Lee, D.G.; Lee, K.S.; Shim, J.J.; Yoon, S.M.; Bae, H.G. Prognostic value of the C-reactive protein levels in the head injury. J. Korean Neurotraumatol. Soc. 2005, 1, 57-60. [CrossRef] 
23. Ridker, P.M. Clinical Application of C-Reactive Protein for Cardiovascular Disease Detection and Prevention. Circulation 2003, 107, 363-369. [CrossRef]

24. Yudkin, J.S.; Stehouwer, C.D.; Emeis, J.J.; Coppack, S.W. C-reactive protein in healthy subjects: Associations with obesity, insulin resistance, and endothelial dysfunction: A potential role for cytokines originating from adipose tissue? Arterioscler. Thromb. Vasc. Biol. 1999, 19, 972-978. [CrossRef] [PubMed]

25. Afari, N.; Mostoufi, S.; Noonan, C.; Poeschla, B.; Succop, A.; Chopko, L.; Strachan, E. C-Reactive Protein and Pain Sensitivity: Findings from Female Twins. Ann. Behav. Med. 2011, 42, 277-283. [CrossRef] [PubMed]

26. Ekiye, A.; Sylvester, I.E.; Pius, I. High Sensitivity C-Reactive Protein in Patients with Acute Injuries. IOSR J. Dent. Med. Sci. 2015, 14, 94-98.

27. Kao, P.C.; Shiesh, S.C.; Wu, T.J. Serum C-Reactive Protein as a Marker for Wellness Assessment. Ann. Clin. Lab. Sci. 2006, 36, 163-169. [PubMed]

28. Smith, R.P.; Lipworth, B.J.; Cree, I.A.; Spiers, E.M.; Winter, J.H. C-reactive protein. A clinical marker in community-acquired pneumonia. Chest 1995, 108, 1288-1291. [CrossRef] [PubMed]

29. Giannoudis, P.V.; Smith, M.R.; Evans, R.T.; Bellamy, M.C.; Guillou, P.J. Serum CRP and IL-6 levels after trauma. Not predictive of septic complications in 31 patients. Acta Orthop. Scand. 1998, 69, 184-188. [CrossRef] [PubMed]

30. Aher, V.; Chander, P.M.; Ali, F.M. C-reactive protein a better indicator of inflammation after third molar extraction. Niger. J. Clin. Pract. 2013, 16, 297. [CrossRef]

31. Ren, Y.-F.; Malmstrom, H.S. Rapid quantitative determination of C-reactive protein at chair side in dental emergency patients. Oral Surg. Oral Med. Oral Pathol. Oral Radiol. Endodontol. 2007, 104, 49-55. [CrossRef]

32. Irshad, A.S.; Mohamad, I.; Shahid, H.; Tajamul, H.; Zahoor, T. The CRP levels in patients of alveolar osteitis treated with eugional and Honey-Research. IOSR J. Dent. Med. Sci. 2015, 14, 57-61.

33. Graziani, F.; D'Aiuto, F.; Gennai, S.; Petrini, M.; Nisi, M.; Cirigliano, N.; Landini, L.; Bruno, R.; Taddei, S.; Ghiadoni, L. Systemic Inflammation after Third Molar Removal: A Case-Control Study. J. Dent. Res. 2017, 96, 1505-1512. [CrossRef]

34. Roberts, W.L.; Sedrick, R.; Moulton, L.; Spencer, A.; Rifai, N. Evaluation of four automated high-sensitivity C-reactive protein methods: Implications for clinical and epidemiological applications. Clin. Chem. 2000, 46, 461-468. [CrossRef] [PubMed]

35. Wilkins, J.; Gallimore, J.R.; Moore, E.G.; Pepys, M.B. Rapid automated high sensitivity enzyme immunoassay of C-reactive protein. Clin. Chem. 1998, 44 Pt 1, 1358-1361. [CrossRef]

36. Rifai, N.; Tracy, R.P.; Ridker, P.M. Clinical efficacy of an automated high-sensitivity C-reactive protein assay. Clin. Chem. 1999, 45, 2136-2141. [CrossRef]

37. Roberts, W.L.; Moulton, L.; Law, T.C.; Farrow, G.; Cooper-Anderson, M.; Savory, J.; Rifai, N. Evaluation of nine automated high-sensitivity C-reactive protein methods: Implications for clinical and epidemiological applications. Part 2. Clin. Chem. 2001, 47, 418-425. [CrossRef] [PubMed]

38. Cei, S.; D'Aiuto, F.; Duranti, E.; Taddei, S.; Gabriele, M.; Ghiadoni, L.; Graziani, F. Third molar surgical removal: A posiible model of human systemic inflamation? A preliminary investigation. Eur. J. Inflamm. 2012, 10, 149-152. [CrossRef]

39. Mantilla Gomez, S.; Danser, M.M.; Sipos, P.M.; Rowshani, B.; van der Velden, U.; van der Weijden, G.A. Tongue coating and salivary bacterial counts in healthy/gingivitis subjects and periodontitis patients. J. Clin. Periodontol. 2001, 28, 970-978. [CrossRef]

40. Al-Hamed, F.S.; Tawfik, M.A.-M.; Abdelfadil, E. Clinical effects of platelet-rich fibrin (PRF) following surgical extraction of lower third molar. Saudi J. Dent. Res. 2017, 8, 19-25. [CrossRef]

41. Fujioka-Kobayashi, M.; Miron, R.J.; Moraschini, V.; Zhang, Y.; Gruber, R.; Wang, H.-L. Efficacy of platelet-rich fibrin on socket healing after mandibular third molar extractions. J. Oral Maxillofac. Surg. Med. Pathol. 2021, 33, 379-388. [CrossRef]

42. Kim, J.-C.; Choi, S.-S.; Wang, S.-J.; Kim, S.-G. Minor complications after mandibular third molar surgery: Type, incidence, and possible prevention. Oral Surg. Oral Med. Oral Pathol. Oral Radiol. Endodontol. 2006, 102, e4-e11. [CrossRef] [PubMed]

43. Sanchís Bielsa, J.M.; Hernandez Bazan, S.; Peñarrocha Diago, M. Flap repositioning versus conventional suturing in third molar surgery. Med. Oral Patol. Oral Cir. Bucal. 2008, 13, E138-E142.

44. Kareem, J.J. A Comparison between primary and secondary wound closure after surgical removal of lower third molars according to pain and swelling. MDJ 2008, 5, 410-417.

45. Grossi, G.B.; Maiorana, C.; Garramone, R.A.; Borgonovo, A.; Creminelli, L.; Santoro, F. Assessing Postoperative Discomfort After Third Molar Surgery: A Prospective Study. J. Oral Maxillofac. Surg. 2007, 65, 901-917. [CrossRef] [PubMed]

46. Osunde, O.; Adebola, R.; Saheeb, B. A comparative study of the effect of suture-less and multiple suture techniques on inflammatory complications following third molar surgery. Int. J. Oral Maxillofac. Surg. 2012, 41, 1275-1279. [CrossRef]

47. Garcia Garcia, A.; Gude Sampedro, F.; Gandara Rey, J.; Gallas Torreira, M. Trismus and pain after removal of impacted lower third molars. J. Oral Maxillofac. Surg. 1997, 55, 1223-1226. [CrossRef]

48. Townend, J. Third molar surgery: An audit of the indications for surgery, postoperative complaints and patient satisfaction. Br. J. Oral Maxillofac. Surg. 1995, 33, 265. [CrossRef]

49. Dolanmaz, D.; Esen, A.; Isik, K.; Candirli, C. Effect of 2 flap designs on postoperative pain and swelling after impacted third molar surgery. Oral Surg. Oral Med. Oral Pathol. Oral Radiol. 2013, 116, e244-e246. [CrossRef] [PubMed]

50. Yuasa, H.; Sugiura, M. Clinical postoperative findings after removal of impacted mandibular third molars: Prediction of postoperative facial swelling and pain based on preoperative variables. Br. J. Oral Maxillofac. Surg. 2004, 42, 209-214. [CrossRef] 
51. Hashemi, H.M.; Beshkar, M.; Aghajani, R. The effect of sutureless wound closure on postoperative pain and swelling after impacted mandibular third molar surgery. Br. J. Oral Maxillofac. Surg. 2012, 50, 256-258. [CrossRef] [PubMed]

52. Pasqualini, D.; Cocero, N.; Castella, A.; Mela, L.; Bracco, P. Primary and secondary closure of the surgical wound after removal of impacted mandibular third molars: A comparative study. Int. J. Oral Maxillofac. Surg. 2005, 34, 52-57. [CrossRef] [PubMed]

53. Gaya, V.O.; Capilla, M.V.; Mateos, R.G. Relación de las variables del paciente y de la intervención con el dolor y la inflamación postoperatorios en la exodoncia de los terceros molares. Med. Oral. 2002, 7, 360-369.

54. de Santana-Santos, T.; de Souza-Santos, A.; Martins-Filho, P.R.; da Silva, L.C.; de Oliveira, E.S.E.D.; Gomes, A.C. Prediction of postoperative facial swelling, pain and trismus following third molar surgery based on preoperative variables. Med. Oral Patol. Oral Cir. Bucal. 2013, 18, e65-e70. [CrossRef]

55. Al-Samman, A.A. Pattern of Pain and Swelling after Periapical and Wisdom Tooth Surgery: Are age and Gender Predictive Factors? Iraqi Dent. J. 2017, 39, 51-58. [CrossRef]

56. Al-Belasy, F.A. The relationship of "shisha" (water pipe) smoking to postextraction dry socket. J. Oral Maxillofac. Surg. 2004, 62, 10-14. [CrossRef] [PubMed]

57. Haraji, A.; Rakhshan, V.; Khamverdi, N.; Alishahi, H.K. Effects of intra-alveolar placement of $0.2 \%$ chlorhexidine bioadhesive gel on dry socket incidence and postsurgical pain: A double-blind split-mouth randomized controlled clinical trial. J. Orofac. Pain 2013, 27, 256-262. [CrossRef]

58. Eshghpour, M.; Dastmalchi, P.; Nekooei, A.H.; Nejat, A. Effect of Platelet-Rich Fibrin on Frequency of Alveolar Osteitis Following Mandibular Third Molar Surgery: A Double-Blinded Randomized Clinical Trial. J. Oral Maxillofac. Surg. 2014, 72, $1463-1467$. [CrossRef]

59. Blondeau, F.; Daniel, N.G. Extraction of Impacted Mandibular Third Molars: Postoperative Complications and Their Risk Factors. JCDA 2007, 73, 325e.

60. Singh, V.; Soni, N.; Mohammad, S.; Singh, R.; Pal, U.; Singh, R.; Aggrwal, J.; Pal, M. Effects of honey in the management of alveolar osteitis: A study. Natl. J. Maxillofac. Surg. 2016, 7, 136-147. [CrossRef]

61. Mamoun, J. Dry Socket Etiology, Diagnosis, and Clinical Treatment Techniques. J. Korean Assoc. Oral Maxillofac. Surg. 2018, 44, 52-58. [CrossRef] [PubMed]

62. Kolokythas, A.; Olech, E.; Miloro, M. Alveolar Osteitis: A Comprehensive Review of Concepts and Controversies. Int. J. Dent. 2010, 2010, 1-10. [CrossRef]

63. Gowda, G.G.; Viswanath, D.; Kumar, M.; Umashanker, D. Dry Socket (Alveolar Osteitis): Incidence, Pathogenesis, Prevention and Management. J. Indian Acad. Oral Med. Radiol. 2013, 25, 196-199.

64. Blum, I. Contemporary views on dry socket (alveolar osteitis): A clinical appraisal of standardization, aetiopathogenesis and management: A critical review. Int. J. Oral Maxillofac. Surg. 2002, 31, 309-317. [CrossRef] [PubMed]

65. Hoaglin, D.R.; Lines, G.K. Prevention of Localized Osteitis in Mandibular Third-Molar Sites Using Platelet-Rich Fibrin. Int. J. Dent. 2013, 2013, 1-4. [CrossRef] [PubMed]

66. Al-Hamed, F.S.; Tawfik, M.A.-M.; Abdelfadil, E.; Al-Saleh, M.A. Efficacy of Platelet-Rich Fibrin After Mandibular Third Molar Extraction: A Systematic Review and Meta-Analysis. J. Oral Maxillofac. Surg. 2017, 75, 1124-1135. [CrossRef]

67. Asutay, F.; Geçör, O.; Acar, A.; Öztürk, S.; Malkoç, S. An evaluation of effects of platelet-rich-fibrin on postoperative morbidities after lower third molar surgery. Niger. J. Clin. Pract. 2016, 20, 1531-1536. [CrossRef]

68. Rutkowski, J.L.; Fennell, J.W.; Kern, J.C.; Madison, D.E.; Johnson, D.A. Inhibition of alveolar osteitis in mandibular tooth extraction sites using platelet-rich plasma. J. Oral Implantol. 2007, 33, 116-121. [CrossRef]

69. Ratiu, C.; Brocks, M.; Costea, T.; Moldovan, L.; Cavalu, S. PRGF-Modified Collagen Membranes for Guided Bone Regeneration: Spectroscopic, Microscopic and Nano-Mechanical Investigations. Appl. Sci. 2019, 9, 1035. [CrossRef] 